\title{
Metabolic effects of vitamin D active metabolites in monolayer and micromass cultures of nucleus pulposus and annulus fibrosus cells isolated from human intervertebral disc
}

\author{
Alessandra Colombini ${ }^{\mathrm{a}, *}$, Patrizia Lanteri ${ }^{\mathrm{a}}$, Giovanni Lombardi ${ }^{\mathrm{a}}$, Dalila Grasso ${ }^{\mathrm{a}}$, Camilla Recordati $^{\mathrm{b}}$, \\ Alessio Lovi ${ }^{\mathrm{a}}$, Giuseppe Banfi ${ }^{\mathrm{a}, \mathrm{c}}$, Roberto Bassani ${ }^{\mathrm{a}}$, Marco Brayda-Bruno ${ }^{\mathrm{a}}$ \\ a I.R.C.C.S. Istituto Ortopedico Galeazzi, Via R. Galeazzi 4, 20161 Milano, Italy \\ ${ }^{\mathrm{b}}$ Mouse and Animal Pathology Laboratory, Fondazione Filarete, Viale Ortles 22/4, 20139 Milano, Italy \\ c School of Medicine, University of Milan, Milano, Italy
}

\section{A R T I C L E I N F O}

\section{Article history:}

Received 16 January 2012

Accepted 21 March 2012

Available online 28 March 2012

\section{Keywords:}

Intervertebral disc cells

Vitamin $\mathrm{D}$ receptor

$1,25(\mathrm{OH})_{2} \mathrm{D}_{3}$

Proliferation

Matrix genes expression

\begin{abstract}
A B S T R A C T
Intragenic polymorphisms in the vitamin D receptor gene are linked to disc degeneration features, suggesting that alterations in the vitamer-mediated signalling could be involved in the pathophysiology of the disc and that interaction of disc cells with vitamin D metabolites may be critical for disc health.

The vitamer-mediated modulation of disc cells proliferation, metabolic activity, extracellular matrix (ECM) genes expression and proteins production was investigated.

It was stated that disc cells express vitamin $\mathrm{D}$ receptor and are very sensitive to metabolic stimuli.

In monolayer cultures, $1,25(\mathrm{OH})_{2} \mathrm{D}_{3}$, but not $24,25(\mathrm{OH})_{2} \mathrm{D}_{3}$, determined an inhibition of the proliferation and regulated also the ECM genes expression in nucleus pulposus and annulus fibrosus cells.

Micromass cultures induced a more physiologic expression pattern of extracellular matrix genes. Cells Treatment with vitamin D metabolites did not result in relevant modifications of glycosaminoglycans production, except for annulus cells, whose production was reduced after $1,25(\mathrm{OH})_{2} \mathrm{D}_{3}$ treatment. Moreover, a reduced glycosaminoglycans staining in both cell types and a significant reduced aggrecan gene expression in annulus cells treated with $1,25(\mathrm{OH})_{2} \mathrm{D}_{3}$ were observed. A reduction of collagen I and II staining in annulus cells $1,25(\mathrm{OH})_{2} \mathrm{D}_{3}$ treated, in accordance with a downregulation of collagen genes expression, was also registered.

Finally, the vitamin D receptor gene expression did not show significant metabolite-mediated modification in monolayer or micromass cultures.

These findings could enhance new insights on the biochemical mechanisms regulated by vitamin $\mathrm{D}$ in disc cartilage and possibly involved in the development of physiological/pathological modifications of the disc.
\end{abstract}

(c) 2012 Elsevier Ltd. All rights reserved.

\section{Introduction}

The intervertebral disc (IVD) is an heterogeneous structure; its functional properties strikingly depend on the composition, organization and integrity of the extracellular matrix (ECM) produced and maintained by a few resident cells. Alterations in cellular metabolism adversely affect the ECM composition and its functional properties, providing a starting point for disc degeneration (Colombini et al., 2008).

Disc cells belong to phenotypically distinct populations differing in the overall expression and production of specific matrix

\footnotetext{
* Corresponding author. Tel.: +39 0266214068; fax: +39 0266214060.

E-mail address: alessandra.colombini@grupposandonato.it (A. Colombini).
}

components (Roberts et al., 2006; Setton and Chen, 2004). Nucleus pulposus (NP) cells are specialized in the synthesis of sulphated glycosaminoglycans (GAGs), mainly aggrecan, and collagen type II, while annulus fibrosus (AF) cells mainly synthesize both collagen types I and II (Roberts et al., 2006; Urban and Roberts, 2003).

IVD cells are exposed to vitamin $\mathrm{D}$ metabolites and they interact with $25(\mathrm{OH}) \mathrm{D}_{3}, 24,25(\mathrm{OH})_{2} \mathrm{D}_{3}$ and $1,25(\mathrm{OH})_{2} \mathrm{D}_{3}$ present in plasma and in cerebrospinal fluid, diffusing into the disc during motion (Balabanova et al., 1984).

Some studies showed an association between intragenic polymorphisms of the vitamin D receptor (VDR) gene and disc degeneration (Videman et al., 1998, 2001; Jones et al., 1998; Kawaguchi et al., 2002), suggesting that biologic interaction of disc cells with the vitamin D metabolites may be critical for disc health 
Table 1

Demographic features of patients recruited for the study and characteristics of the disc samples collected.

\begin{tabular}{|c|c|c|c|c|c|}
\hline Sex & Age & Surgical indication & $\begin{array}{l}\text { Disc } \\
\text { specimens }\end{array}$ & $\begin{array}{l}\text { Disc de generation } \\
\text { (grade) }\end{array}$ & $\begin{array}{l}\text { Type of } \\
\text { sample }\end{array}$ \\
\hline $\mathrm{F}$ & 32 & Discopathy & L5-S1 & V & NP-AF \\
\hline $\mathrm{F}$ & 33 & Discopathy & L5-S1 & V & NP-AF \\
\hline $\mathrm{F}$ & 34 & Hernia and discopathy & L5-S1 & IV & NP-AF \\
\hline \multirow[t]{2}{*}{$\mathrm{F}$} & 37 & Degenerative discopathy & L4-L5 & III & NP-AF \\
\hline & & & L5-S1 & III-IV & NP-AF \\
\hline $\mathrm{F}$ & 45 & Discopathy & L5-S1 & IV & NP-AF \\
\hline $\mathrm{F}$ & 53 & Spondylolisthesis and discopathy & L5-S1 & IV & NP-AF \\
\hline $\mathrm{F}$ & 53 & Degenerative lumbar spondylolisthesis and discopathy & L5-S1 & IV & NP-AF \\
\hline M & 29 & Osteochondrosis and discopathy & L5-S1 & $\mathrm{V}$ & NP-AF \\
\hline M & 40 & Discopathy & L5-S1 & III & NP-AF \\
\hline M & 47 & Osteochondrosis & L4-L5 & $\mathrm{V}$ & NP-AF \\
\hline M & 50 & Osteochondrosis & L2-L3 & $\mathrm{V}$ & NP-AF \\
\hline M & 51 & Hernia and discopathy & L5-S1 & IV & NP-AF \\
\hline
\end{tabular}

and that an altered vitamin D signalling could have a role in the pathophysiology of the IVD degeneration.

In human, vitamin $\mathrm{D}$ is metabolized throughout two consecutive hydroxylations, producing two hydroxylated, biologically active, vitamin D metabolites (Holick, 2004).

At the molecular level, $1,25(\mathrm{OH})_{2} \mathrm{D}_{3}$ acts through its binding to the VDR, regulating the transcription of target genes, or through transmembrane signal transduction pathways, inducing rapid, nontranscriptional responses (Nemere et al., 1998).

Apart from their well known actions at intestinal, renal and bone levels in regulating calcium and phosphate homeostasis, vitamin D active metabolites, seem to be involved in cartilage metabolism.

In vitro transformation of $25(\mathrm{OH}) \mathrm{D}_{3}$ into $24,25(\mathrm{OH})_{2} \mathrm{D}_{3}$, observed in cultured chondrocytes (Garabedian et al., 1978), and the presence of immunoreactive VDR in their nucleoli, suggest that vitamin $\mathrm{D}$ is directly involved in the differentiation, proliferation and maturation of cartilage cells (Balmain et al., 1993).

Vitamin $\mathrm{D}$ is also involved in cartilage mineralization and endochondral ossification: its deficiency leads to disturbed calcification of growth cartilage and enlargement of growth plate, demonstrating that chondrocytes are a target of the vitamer. $1,25(\mathrm{OH})_{2} \mathrm{D}_{3}$ acts on growth zone chondrocytes during the endochondral ossification, while $24,25(\mathrm{OH})_{2} \mathrm{D}_{3}$ acts on resting zone (mineralization zone) chondrocytes (Klaus et al., 1991; Schwartz et al., 1993; Harmand et al., 1984). Particularly, $1,25(\mathrm{OH})_{2} \mathrm{D}_{3}$ has a specific biphasic effect on cell proliferation and density (stimulation at $10^{-12} \mathrm{M}$ physiological concentration and dose-dependent inhibition at $10^{-10} \mathrm{M}$ and below) (Klaus et al., 1991). Moreover, inhibition of cells proliferation occurs in vitro in response to $1,25(\mathrm{OH})_{2} \mathrm{D}_{3}$ and $24,25(\mathrm{OH})_{2} \mathrm{D}_{3}$ in human and rabbit articular cartilage (Harmand et al., 1984).

Vitamin D active metabolites also have differential effects on extracellular matrix synthesis and cells replication, depending on the distinct stages of chondrocytes differentiation (Schwartz et al., 1993). 1,25( $\mathrm{OH})_{2} \mathrm{D}_{3}$ decreases collagen synthesis in normal and rachitic chick growth cartilage, but not in non calcifying articular and sternal cartilage (Dickson and Maher, 1985); moreover, vitamin $\mathrm{D}$ metabolites directly influence the differentiation and maturation of chondrocytes in calcifying cartilage (Atkin et al., 1985). $1,25(\mathrm{OH})_{2} \mathrm{D}_{3}$ and $24,25(\mathrm{OH})_{2} \mathrm{D}_{3}$ stimulate proteoglycans synthesis and secretion (Corvol et al., 1978); besides, they are differently active on the cellular metabolism of cultured chondrocytes isolated from rabbit growth plate cartilage: $24,25(\mathrm{OH})_{2} \mathrm{D}_{3}$ stimulates the proteoglycan synthesis by mature articular chondrocytes, while $1,25(\mathrm{OH})_{2} \mathrm{D}_{3}$ increases DNA polymerase activities in chondrocytes during the logarithmic phase of division (Corvol et al., 1981).

Finally, vitamin $\mathrm{D}_{3}$ metabolites regulate, via protein kinase $\mathrm{C}$ dependent phosphorylation, specific metalloproteases production, involved in the matrix protein degradation of cartilage growth plate (Schmitz et al., 1996).

Gruber HE et al. observed that cells of the human AF express the VDR in vivo and in vitro and investigated the effect of in vitro administration of vitamin D metabolites on annulus cells. Exposure to $1,25(\mathrm{OH})_{2} \mathrm{D}_{3}$ significantly reduced cell proliferation, but did not affected proteoglycan production. Moreover $1,25(\mathrm{OH})_{2} \mathrm{D}_{3}$ or $24,25(\mathrm{OH})_{2} \mathrm{D}_{3}$-treated cells showed variable production of different cellular mediators and specific cytokines (Gruber et al., 2008).

Since structural changes in the ECM are an important component of disc degeneration and, since the vitamer regulates tissue cells proliferation, matrix proteins synthesis and specific cytokines production in cartilage, alterations in the VDR signalling pathway could be directly involved in the pathophysiology of the degenerated disc.

Based on these evidences we aimed to investigate the effect of $1,25(\mathrm{OH})_{2} \mathrm{D}_{3}$ and $24,25(\mathrm{OH})_{2} \mathrm{D}_{3}$ on human NP and AF cells, and, particularly, to evaluate a possible regulation of cells proliferation, metabolic activity, ECM genes expression and proteins production.

\section{Methods}

\subsection{Study population and disc samples collected}

Lumbar disc specimens were obtained, following informed consent patients signature, from surgical disc procedures performed on 12 patients, with disc diseases. Specimens were graded using the Pfirrmann scoring system (Pfirrmann et al., 2001). Demographic features and disc sites are listed in Table 1.

\subsection{Materials}

Cell culture media and all other reagents, unless otherwise specified, were purchased from Life Technologies (Life Technologies, Grand Island, NY, USA). Fetal bovine serum (FBS) was from Lonza (Lonza Group Ltd., Basel, Switzerland). 1,25( $\mathrm{OH})_{2} \mathrm{D}_{3}$ and $24,25(\mathrm{OH})_{2} \mathrm{D}_{3}$ were from Merck (Merck KGaA, Darmstadt, Germany).

\subsection{Isolation and culture of IVD cells}

NP and AF cells were isolated from human fresh tissue specimens within $1 \mathrm{~h}$ from surgical disc procedures, as previously reported (Neidlinger-Wilke et al., 2005). Tissue digestion was performed with collagenase type I (Worthington Biochemical Corp., Lakewood, NJ, USA), $0.8 \mathrm{mg} / \mathrm{mL}$ for NP and $3 \mathrm{mg} / \mathrm{mL}$ for AF samples, added to the medium containing minced tissue and left for $17-18 \mathrm{~h}$ on mild agitation at $37^{\circ} \mathrm{C}$. The cell suspensions were filtered by $40 \mu \mathrm{m}$ cells strainer, the digestion was blocked with 


\section{Proliferation}
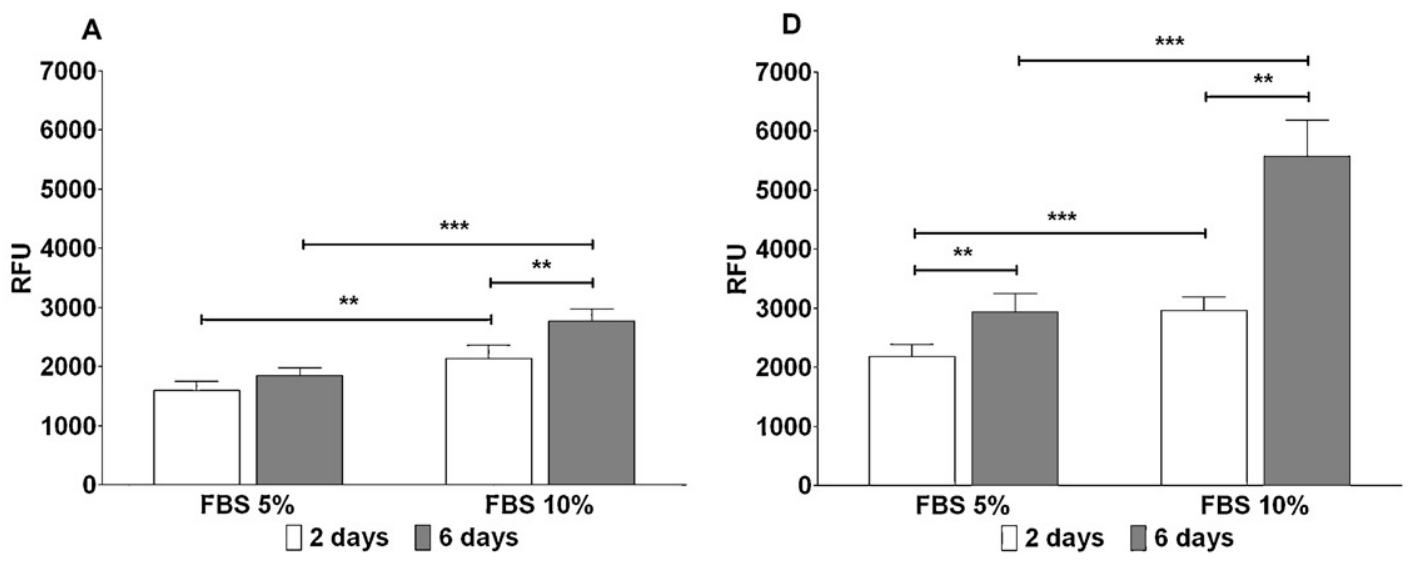

Metabolic activity

B

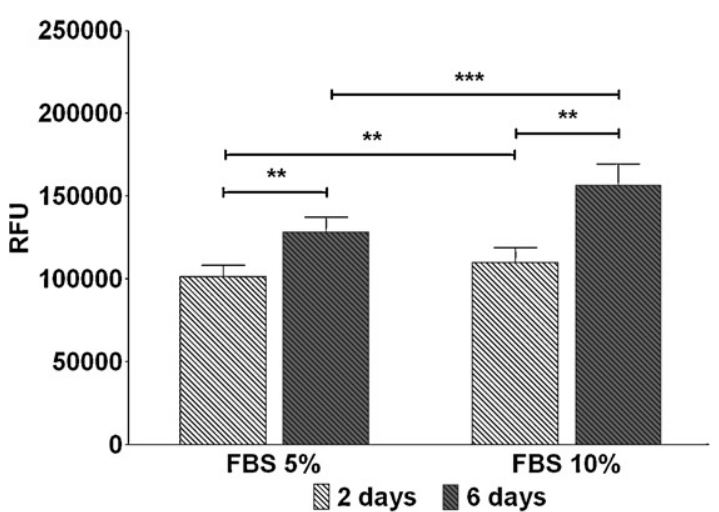

E

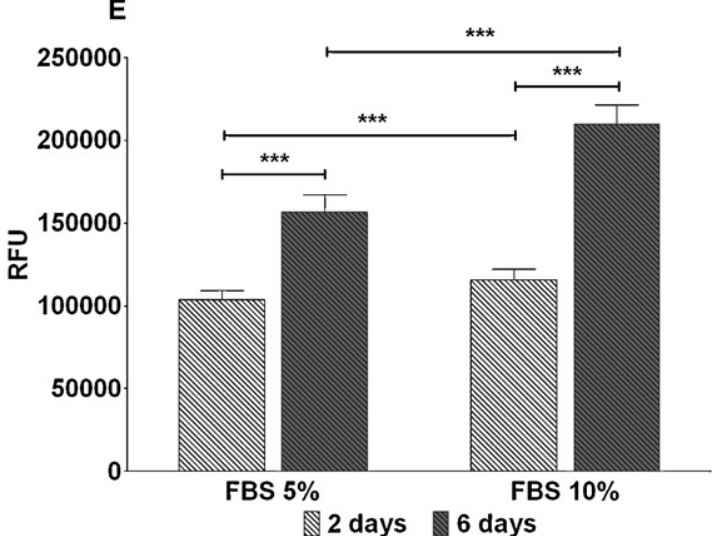

Metabolic activity normalized
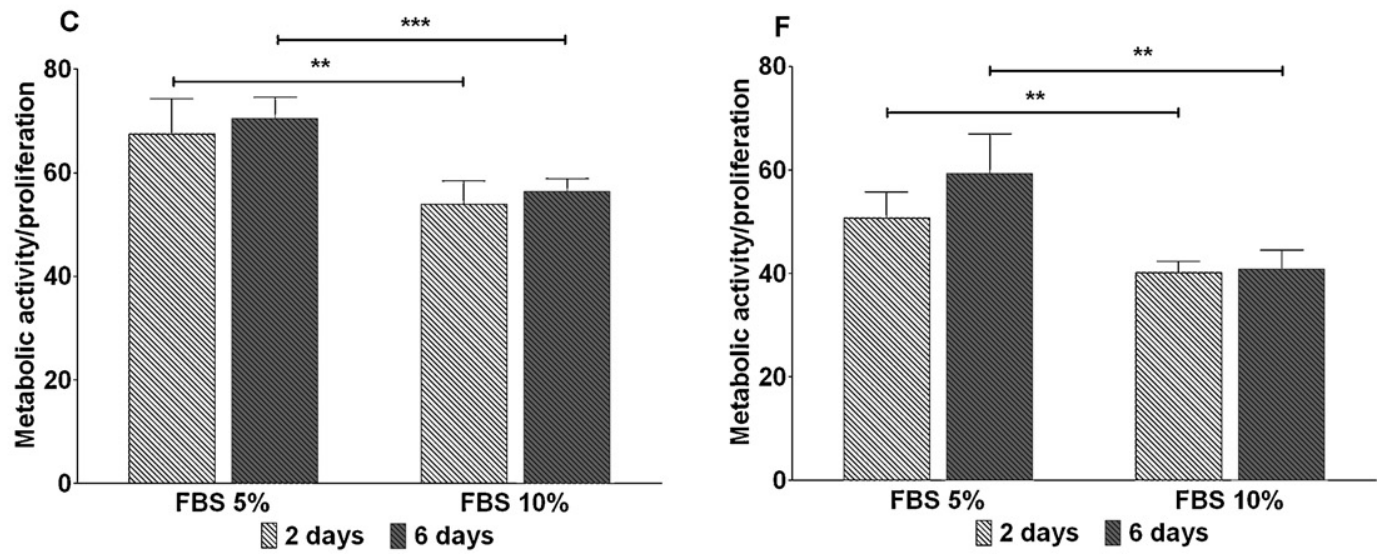

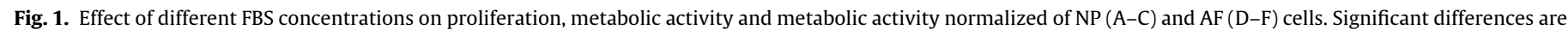
marked as follow: ${ }^{* *} p \leq 0.005$ and ${ }^{* * *} p \leq 0.0005$. RFU, Relative Fluorescence Unit. $n=10$ experiments.

medium containing 10\% FBS and cells were centrifuged at $1000 \times g$ for $5 \mathrm{~min}$. Cells viability was checked by trypan blue vital count and, when $\geq 95 \%$, cells were seeded at a density of $1 \times 10^{5} / \mathrm{cm}^{2}$ in DMEM containing $1 \mathrm{mM}$ sodium pyruvate, $1000 \mathrm{mg} / \mathrm{L}$ D-glucose, $100 \mathrm{U} / \mathrm{ml}$ penicillin, $100 \mu \mathrm{g} / \mathrm{mL}$ streptomycin sulphate and $2.5 \mu \mathrm{g} / \mathrm{mL}$ amphotericin B, 10\% FBS, 1\% non-essential amino acids, $1 \%$ L-glutamine and $25 \mathrm{mM}$ HEPES. Cultures were kept at $37^{\circ} \mathrm{C}$ in a $5 \% \mathrm{CO}_{2}-95 \%$ air atmosphere and medium was changed every 3 days. When confluence was reached, cells were subcultured with trypsin-EDTA (0.05\% trypsin, $0.02 \%$ EDTA) and expanded for further increase the cells number, seeded at $5 \times 10^{3}$ cells $/ \mathrm{cm}^{2}$ and used for the experiments at the third passage.

\subsection{Micromass cultures}

To obtain micromass cultures $4 \times 10^{5}$ cells were centrifuged for $5 \mathrm{~min}$ at $600 \times \mathrm{g}$ and maintained in cultures for up to 4 weeks in chondrogenic differentiation medium: serum-free DMEM with $4500 \mathrm{mg} / \mathrm{L}$ D-glucose, $1 \%$ non essential amino acids, $1 \%$ L-glutamine, $25 \mathrm{mM}$ HEPES, $100 \mathrm{U} / \mathrm{mL}$ penicillin, $100 \mu \mathrm{g} / \mathrm{mL}$ streptomycin sulphate and $2.5 \mu \mathrm{g} / \mathrm{mL}$ amphotericin $\mathrm{B}, 1 \%$ sodium pyruvate, $1 \%$ ITS + 1 (Sigma-Aldrich, St. Louis, MO, USA), $10 \mathrm{ng} / \mathrm{mL}$ TGF $\beta 1$ (Peprotech, Rocky Hill, NY, USA), 100 nM dexamethasone and $50 \mu \mathrm{g} / \mathrm{mL}$ ascorbic acid 2-phosphate (Mackay et al., 1998). 
A

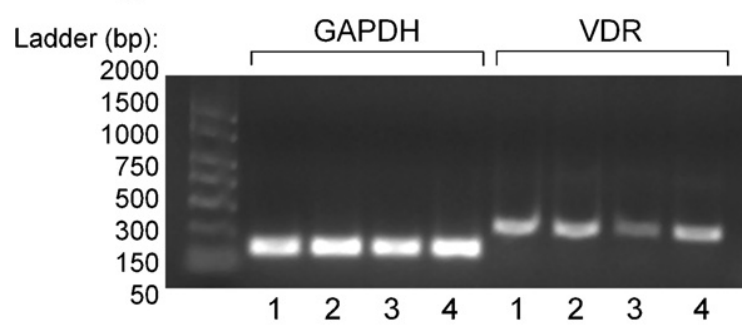

B

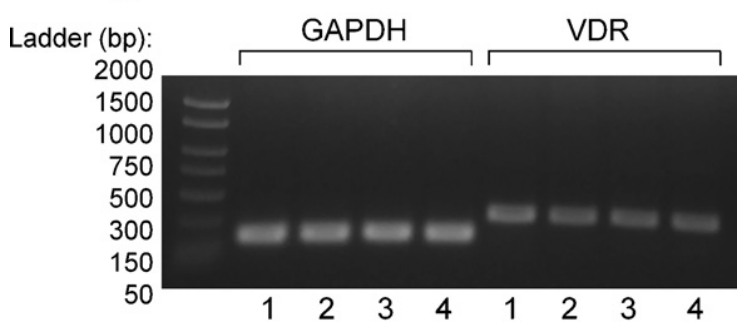

Fig. 2. RT-PCR analysis showed VDR gene expression in NP (A) and AF (B) cells obtained from discs of four different patients $(1,2,3,4)$. GAPDH indicate the housekeeping gene (amplicon $194 \mathrm{bp}$ ) and VDR indicate the vitamin D receptor gene (amplicon $308 \mathrm{bp}$ )

\subsection{Treatment protocols}

Monolayer cultured cells were allowed to attach for $24 \mathrm{~h}$ in standard culture medium. The cultures were then fed either with standard culture medium (10\% FBS) or with low serum medium ( $5 \%$ FBS) added with $10^{-8}$ or $10^{-10} \mathrm{M} 1,25(\mathrm{OH})_{2} \mathrm{D}_{3}$ and $24,25(\mathrm{OH})_{2} \mathrm{D}_{3}$ or vehicle ( $0.1 \%$ DMSO) for a maximum of 12 days after seeding. FBS concentration was reduced to $5 \%$ and the same batch of serum was used in order to decrease the influence of serum, containing the vitamin D binding protein, on the evaluation of the tested parameters.

Micromasses were cultured in chondrogenic differentiation medium for 3 days and then $10^{-8}$ or $10^{-10} \mathrm{M} 1,25(\mathrm{OH})_{2} \mathrm{D}_{3}$ and $24,25(\mathrm{OH})_{2} \mathrm{D}_{3}$ or vehicle were added. Medium was changed every 3 days and micromasses were cultured in these conditions for 28 days.

The timepoints for the monolayer experiments and the metabolites concentrations for both the monolayer and pellet experiments were chosen starting from data reported in a previous published work (Gruber et al., 2008).

\subsection{Evaluation of proliferation and metabolic activity}

Proliferation and viability were evaluated at days 2, 6 after $10^{-8}$ or $10^{-10} \mathrm{M} 1,25(\mathrm{OH})_{2} \mathrm{D}_{3}$ and $24,25(\mathrm{OH})_{2} \mathrm{D}_{3}$ or DMSO treatments, at days 10 and 12 after $10^{-8} \quad 1,25(\mathrm{OH})_{2} \mathrm{D}_{3}$ and DMSO treatments for monolayer cultures and at day 28 after $10^{-8}$ or $10^{-10} \mathrm{M} 1,25(\mathrm{OH})_{2} \mathrm{D}_{3}$ and $24,25(\mathrm{OH})_{2} \mathrm{D}_{3}$ or DMSO treatments for micromass cultures.

Proliferation, as DNA content, was quantitatively evaluated by CyQuant test (Life Technologies). At each time point cells were washed with PBS and freezed at $-80^{\circ} \mathrm{C}$ for at least $24 \mathrm{~h}$ in order to promote cell lysis. Fluorescence emission at $\lambda=520 \mathrm{~nm}$ (excitation $\lambda=480 \mathrm{~nm}$ ) was measured using Perkin Elmer Victor $\mathrm{X}^{3}$ microplate reader (Perkin Elmer Inc., Waltham, MA, USA). The viability was quantitatively assessed through Alamar blue test (Life Technologies) and values were normalized on DNA content. At each time point cells were washed with PBS and incubated for $4 \mathrm{~h}$ with a $10 \%$ Alamar blue serum-free medium solution. Fluorescence emission at $\lambda=580 \mathrm{~nm}$ (excitation $\lambda=540 \mathrm{~nm}$ ) was measured.
Three replicates for CyQuant test and four replicates for Alamar blue test were performed for each experiment.

\subsection{Evaluation of GAGs production}

After 28 days of culture and treatment, micromasses were washed with $\mathrm{PBS}$ and digested at $60^{\circ} \mathrm{C}$ for $16 \mathrm{~h}$ to obtain cells lysates for GAGs quantification, using DMMB assay (Farndale et al., 1986).

Absorbance of the reagent bound with GAGs was measured at $\lambda=525 \mathrm{~nm}$. Sample GAGs concentration was obtained by interpolation of the absorbance values in a chondroitin sulphate (Sigma-Aldrich) standard curve and normalized by DNA concentration. Three replicates of each experiment were performed.

\subsection{RNA extraction, $R T$ and real-time $P C R$}

Total RNA was isolated from cell lysates using the RNeasy Mini kit (Qiagen, Duesseldorf, Germany). RNase-Free DNase Set (Qiagen) was used for residual genomic DNA digestion and the isolated RNA was quantified spectrophotometrically (Nanodrop, Thermo Scientific, Rockford, IL, USA). 100 ng of RNA were reverse-transcripted to cDNA employing the iScript cDNA Synthesis Kit (Bio-Rad Laboratories, Benicia, CA, USA) in a final volume of $20 \mu \mathrm{L}$. The reaction mix was incubated for $5 \mathrm{~min}$ at $25^{\circ} \mathrm{C}, 30 \mathrm{~min}$ at $42^{\circ} \mathrm{C}$ and $5 \mathrm{~min}$ at $85^{\circ} \mathrm{C}$.

In order to assess the expression of VDR in both NP and AF cells, $25 \mathrm{ng}$ of cDNA were used as template for PCR performed using a termocycler (Euroclone, Milano, Italy). PCR mixture included $10 \times$ buffer (200 mM Tris- $\mathrm{HCl}$ pH 8.4, $500 \mathrm{mM} \mathrm{KCl}$ ), $50 \mathrm{mM} \mathrm{MgCl}_{2}$, $10 \mathrm{mM}$ dNTPs, $10 \mu \mathrm{M}$ primers, $5 \mathrm{U} / \mu \mathrm{L}$ Taq Polimerase and sterile water in a final volume of $25 \mu \mathrm{L}$.

The primers for RT-PCR were: for GAPDH forward $5^{\prime}$ CCATGGAGAAGGCTGGGG-3', reverse 5'-CAAAGTTGTCATGGATGACC-3' (194-bp amplificate), for VDR forward $5^{\prime}$ CACTATTCACCTGCCCCTTC-3', reverse 5'-CTCCCTCCACCATCATTCAC-3' (308-bp amplificate). Amplification was performed using the following conditions: $95^{\circ} \mathrm{C}$ for $2 \mathrm{~min}, 30$ cycles of $40 \mathrm{~s}$ at $94{ }^{\circ} \mathrm{C}, 50 \mathrm{~s}$ at $55^{\circ} \mathrm{C}$ and $50 \mathrm{~s}$ at $72^{\circ} \mathrm{C}$ and finally $72^{\circ} \mathrm{C}$ for $5 \mathrm{~min}$. Amplified fragments were separated electrophoretically on $2 \%$ agarose gel.

$10 \mathrm{ng}$ of cDNA was used as template for real-time PCR, performed using a Rotor Gene RG3000 system (Qiagen). PCR mixture included TaqMan Universal PCR Master Mix and Assays-onDemand Gene expression probes in a final volume of $20 \mu \mathrm{L}$. Amplification and real-time data acquisition were performed using the following cycle conditions: $2 \mathrm{~min}$ at $50^{\circ} \mathrm{C}, 10 \mathrm{~min}$ at $95^{\circ} \mathrm{C}$, followed by 40 cycles of $15 \mathrm{~s}$ at $95^{\circ} \mathrm{C}$ and $1 \mathrm{~min}$ at $60^{\circ} \mathrm{C}$. Examined genes were: glyceraldehydes-3-phosphate dehydrogenase $(G A P D H)$, vitamin D receptor (VDR), type I collagen (COL1A1), type II collagen (COL2A1) and aggrecan (ACAN). The fold change in the expression of the different genes in control and treated cells was normalized on the expression of the housekeeping GAPDH gene.

\subsection{Histological and immunohistochemical analysis}

Micromasses of 4 NP and 5 AF samples were fixed in 10\% neutral buffered formalin, embedded in paraffin and sectioned at $4 \mu \mathrm{m}$. Serial sections were stained with Haematoxylin and Eosin (HE) for histological examination and Alcian Blue ( $\mathrm{pH} 2.5$ ) for GAGs detection. Bern Score visual grading system was used for the assessment of the in vitro cartilagineous differentiation (Grogan et al., 2006). For immunohistochemistry, additional sections were immunostained with rabbit polyclonal anti-collagen I (ab34710, Abcam, Cambridge, UK) (working dilution of 1:50), and mouse monoclonal anti-collagen II (SPM239) (ab54236, Abcam) primary antibodies applied at room temperature for $1 \mathrm{~h}$. The sections were labelled with a standard avidin-biotin complex immunoperoxidase kit 


\section{Proliferation}
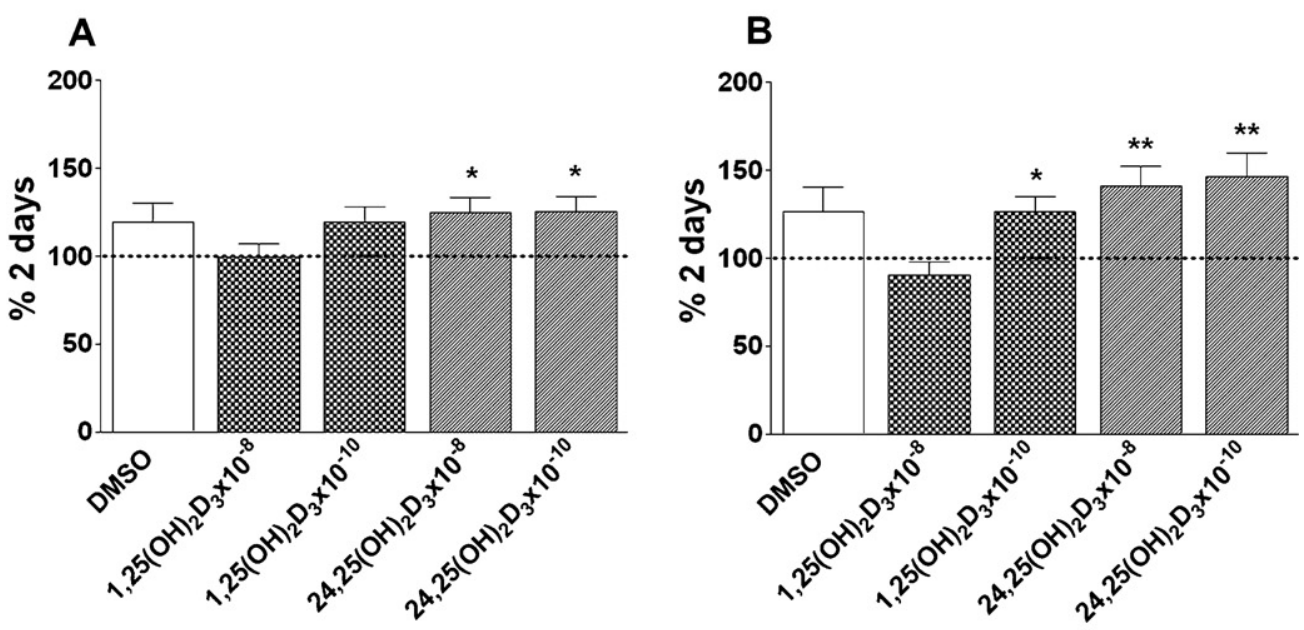

Metabolic activity

C

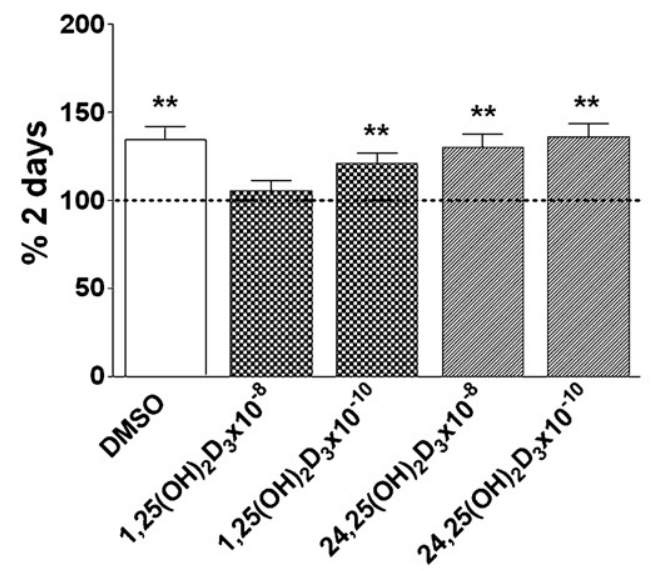

D

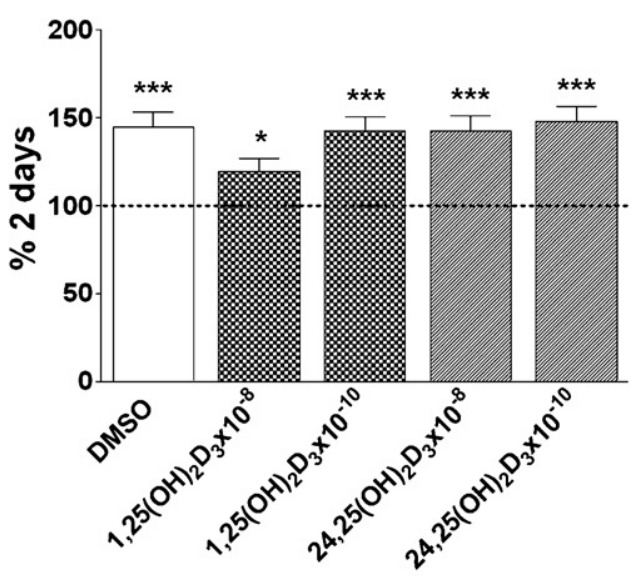

Metabolic activity normalized

E

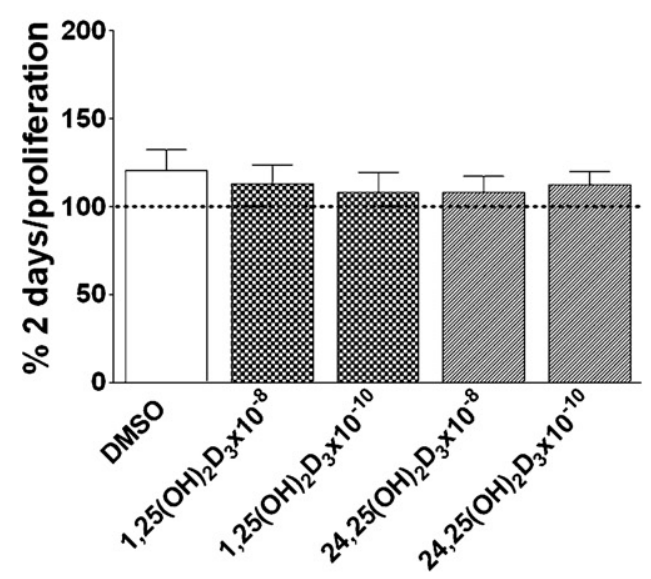

\section{$F$}

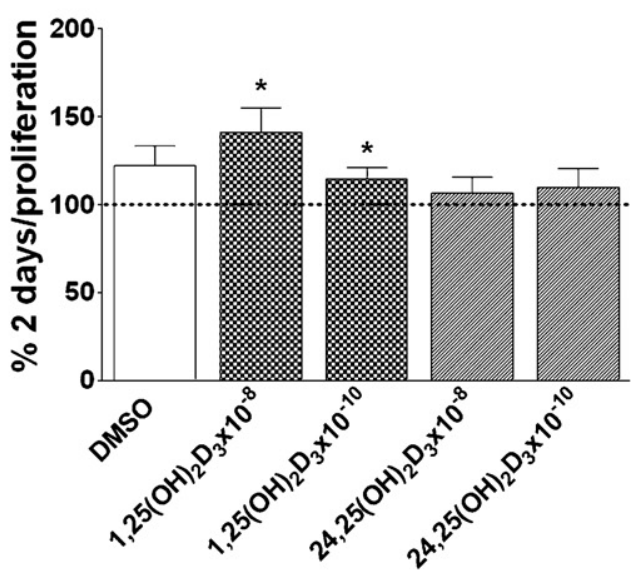

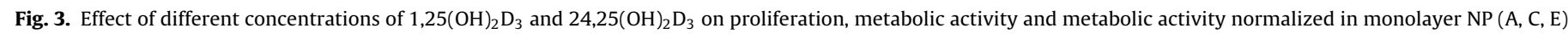

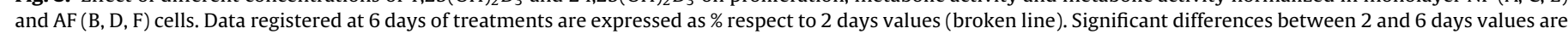
marked as follow: ${ }^{*} p \leq 0.05,{ }^{* *} p \leq 0.005$ and ${ }^{* * *} p \leq 0.0005 . n=10$ experiments.

(Vectastain Standard Elite ABC kit, Vector Laboratories, Burlingame, CA, USA). The immunohistochemical reaction was developed with 3.3' diaminobenzidine (DAB) for 5 min and sections were counterstained for 2 min with Mayer's haematoxylin. Negative controls for each sample were prepared by replacing the primary antibody with PBS containing $10 \%$ normal goat or horse serum. Control sections were included in each immunolabeling assay. Immunostained sections were scored for the presence of collagen I and II staining by 
using a semiquantitative scoring system as follows: $0=$ absence, 1 = mild, 2 = moderate, 3 = marked.

\subsection{Data evaluation and statistics}

Data were expressed as mean \pm SEM and statistical analysis was performed using Student's $t$-test for paired data and One-Way ANOVA with post hoc Newman-Kleus as multiple comparison test (GraphPad Prism v5.00 Software, La Jolla, CA, USA). Level of significance was set at $p \leq 0.05$.

\section{Results}

\subsection{Effect of FBS on proliferation and metabolic activity}

Cells in culture without FBS for $24 \mathrm{~h}$ did not proliferate, assumed a rounded morphology, and began to die and to detach from the growth support.

We analyzed the proliferation and the metabolic activity of disc cells maintained in culture with FBS $10 \%$ and 5\% for 2 and 6 days to evaluate the effect of the reduced serum concentration. Data are expressed as percentage variation versus control considered as $100 \%$.

NP cells proliferation did not significantly increase $(123 \pm 40 \%)$ in cells in 5\% FBS, while in cells in 10\% FBS it significantly $(p \leq 0.005)$ increased $(135 \pm 30 \%)$ from day 2 to day 6 of culture. Moreover, at both 2 and 6 days of culture, cells in 10\% FBS showed a significant ( $p \leq 0.005$ and $p \leq 0.0005$, respectively) higher proliferation $(135 \pm 19 \%$ and $151 \pm 25 \%$, respectively) than cells in $5 \%$ FBS (Fig. 1A).

Metabolic activity of NP cells significantly $(p \leq 0.005)$ increased from day 2 to day 6 with both 5\% and 10\% FBS $(128 \pm 24 \%$ and $144 \pm 28 \%$, respectively). At both 2 and 6 days of culture, cells in $10 \%$ FBS showed a significant ( $p \leq 0.005$ and $p \leq 0.0005$, respectively) higher viability ( $108 \pm 6 \%$ and $121 \pm 13 \%$, respectively) than cells in 5\% FBS (Fig. 1B).

Normalized metabolic activity of NP cells in $10 \%$ FBS showed a significant ( $p \leq 0.005$ and $p \leq 0.0005$, respectively) reduction at 2 and 6 days of culture ( $81 \pm 11 \%$ and $81 \pm 9 \%$, respectively) in comparison with cells in 5\% FBS (Fig. 1C).

Proliferation of AF cells significantly $(p \leq 0.005)$ increased from day 2 to day 6 for both 5\% and 10\% FBS cultured cells $(137 \pm 36 \%$ and $191 \pm 63 \%$, respectively) and both at 2 and 6 days of culture cells in $10 \%$ FBS showed a significant $(p \leq 0.0005)$ higher proliferation $(139 \pm 19 \%$ and $192 \pm 35 \%$, respectively) than cells in $5 \%$ FBS (Fig. 1D).

Metabolic activity of AF cells significantly $(p \leq 0.0005)$ increased from day 2 to day 6 , for both $5 \%$ and $10 \%$ FBS cultured cells $(153 \pm 29 \%$ and $183 \pm 26 \%$, respectively). At 2 and 6 days cells in $10 \%$ FBS showed a significant ( $p \leq 0.0005)$ higher viability $(112 \pm 5 \%$ and $136 \pm 23 \%$, respectively) than cells in 5\% FBS (Fig. 1E).

Normalized metabolic activity of AF cells in 10\% FBS showed a significant $(p \leq 0.005)$ reduction $(82 \pm 11 \%$ and $73 \pm 20 \%$, respectively) at 2 and 6 days of culture in comparison with cells in 5\% FBS (Fig. 1F).

\subsection{VDR gene expression}

Before testing the effect of vitamin $\mathrm{D}_{3}$ metabolites on IVD cells, we evaluated the expression of the gene coding for vitamin D receptor in cells. RT-PCR analysis showed that both cell types express vitamin $\mathrm{D}_{3}$ receptor gene (Fig. 2).
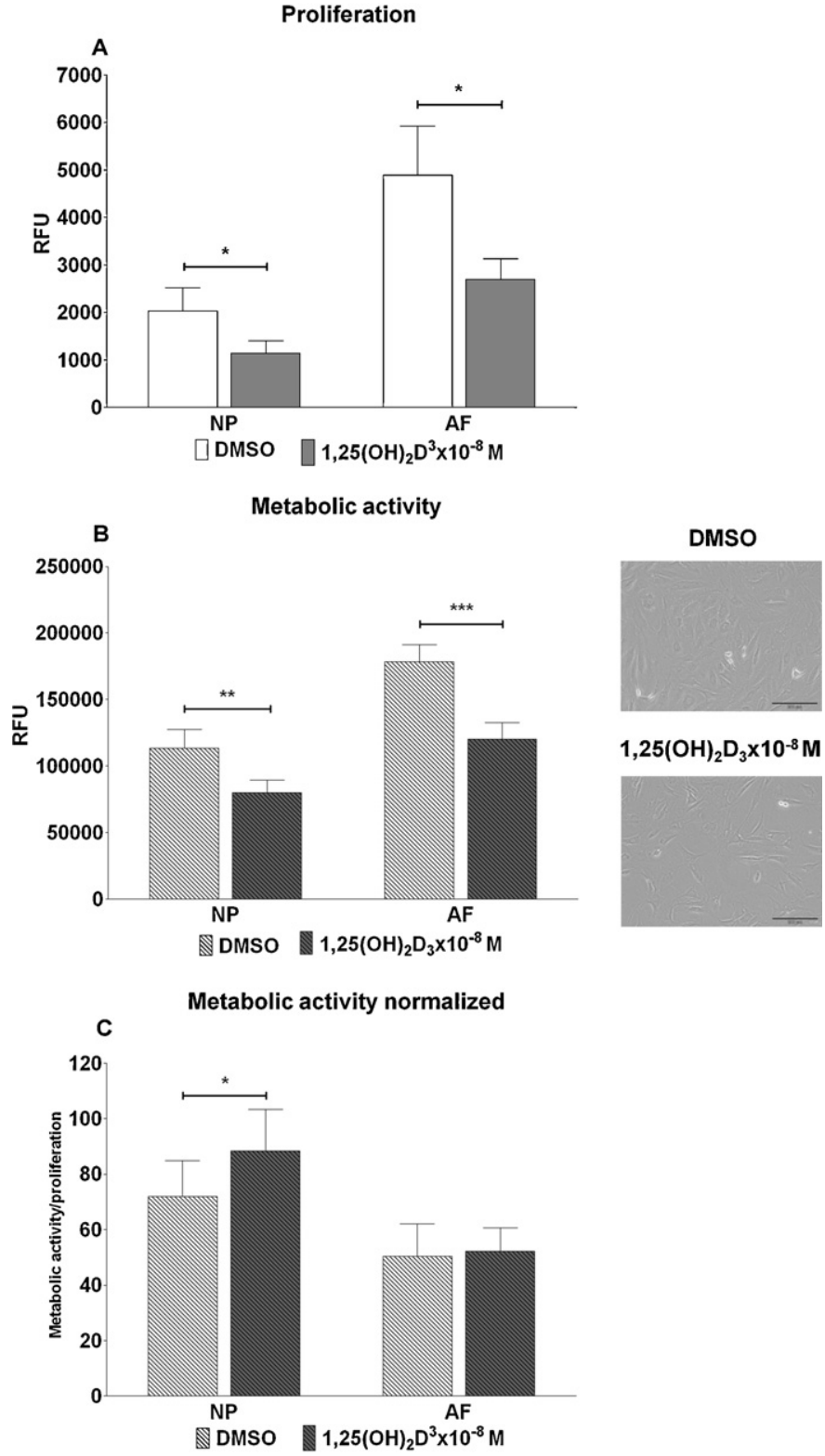

Fig. 4. Effect of $10^{-8} \mathrm{M} 1,25(\mathrm{OH})_{2} \mathrm{D}_{3}$ on cells proliferation (A), metabolic activity (B) and metabolic activity normalized (C) in monolayer after 12 days of treatment. Significant differences are marked as follow: ${ }^{*} p \leq 0.05,{ }^{* *} p \leq 0.005$ and ${ }^{* * *} p \leq 0.0005$ RFU, Relative Fluorescence Unit. $n=10$ experiments. Contrast phase microscope image shows the $10^{-8} \mathrm{M} 1,25(\mathrm{OH})_{2} \mathrm{D}_{3}$ inhibition of proliferation; magnification $10 \times$.

\subsection{Effect of $1,25(\mathrm{OH})_{2} \mathrm{D}_{3}$ and $24,25(\mathrm{OH})_{2} \mathrm{D}_{3}$ on proliferation and metabolic activity in monolayer and micromass culture}

No influences were observed for DMSO treatment on the parameters in comparison with control cells in culture with 5\% FBS. For what concern the effects on proliferation of NP and AF cells, after 2 days, we did not registered significant differences between the treatments, while, after 6 days, cells treated with $10^{-8} \mathrm{M}$ $1,25(\mathrm{OH})_{2} \mathrm{D}_{3}$ showed a significant reduction in the proliferation $(p \leq 0.0005)$ in comparison with cells differently treated (Fig. 3A and $\mathrm{B})$.

Metabolic activity of NP cells after 6 days and AF cells after 2 and 6 days of treatment was significant reduced $(p \leq 0.0005)$ after $10^{-8} \mathrm{M} 1,25(\mathrm{OH})_{2} \mathrm{D}_{3}$ treatment in comparison with cells differently treated (Fig. $3 \mathrm{C}$ and D). 


\section{Proliferation}

A

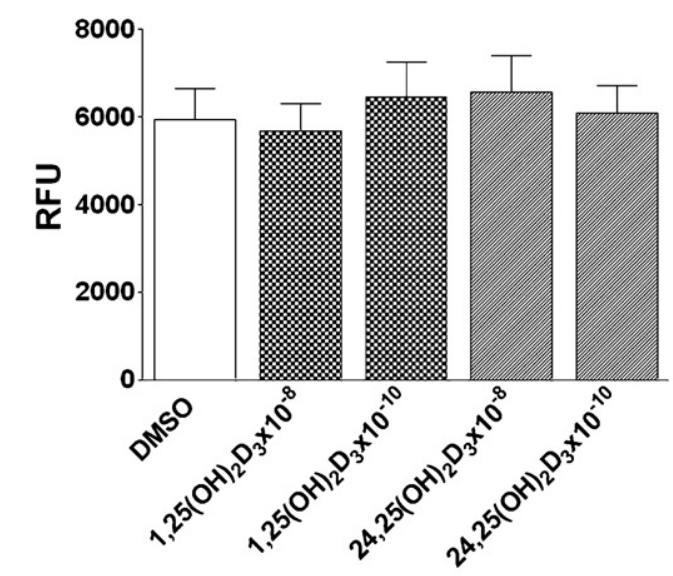

B

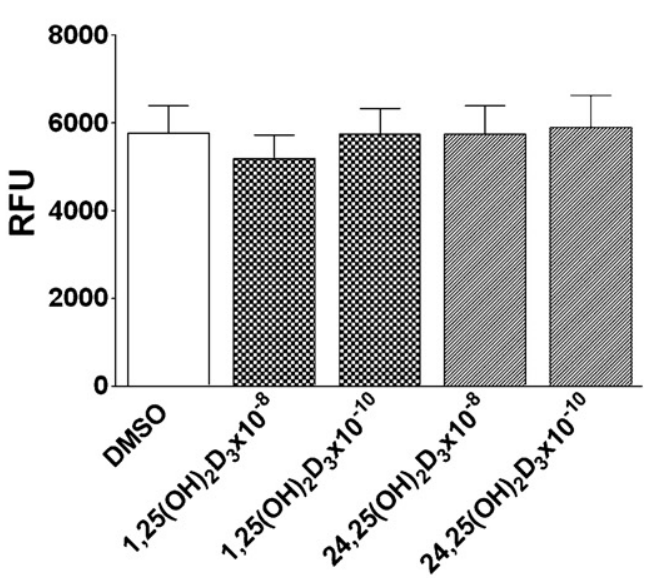

Metabolic activity

C

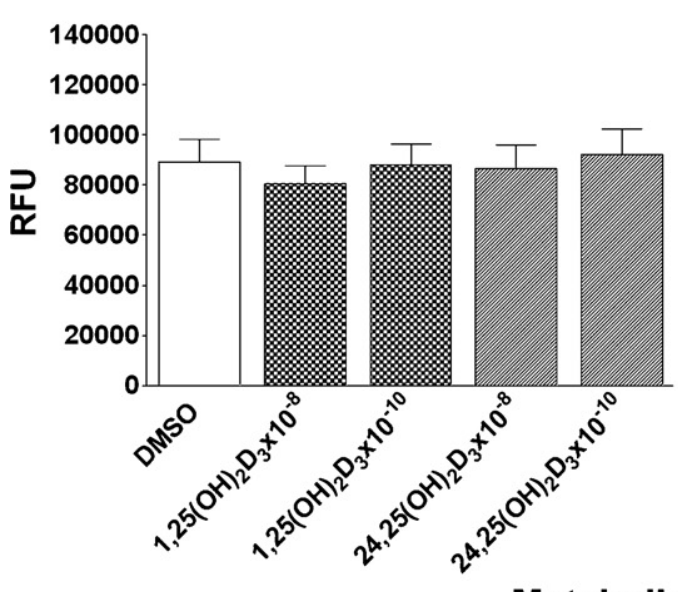

Metabolic activity normalized

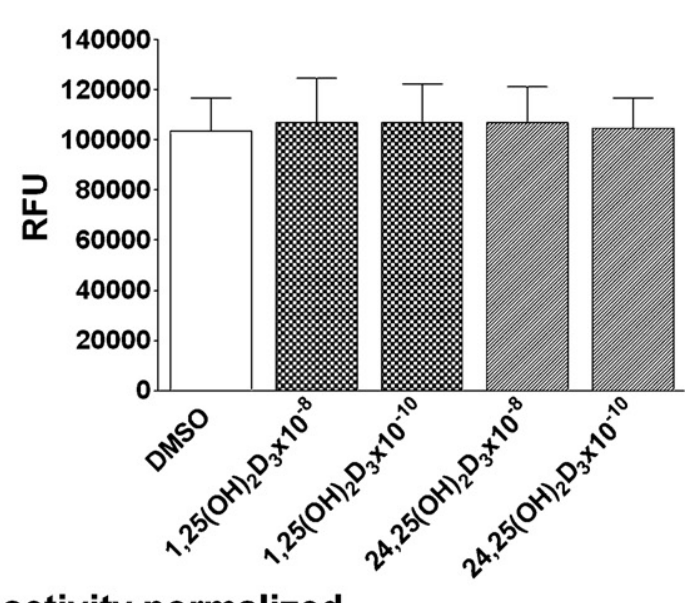

$\mathbf{F}$

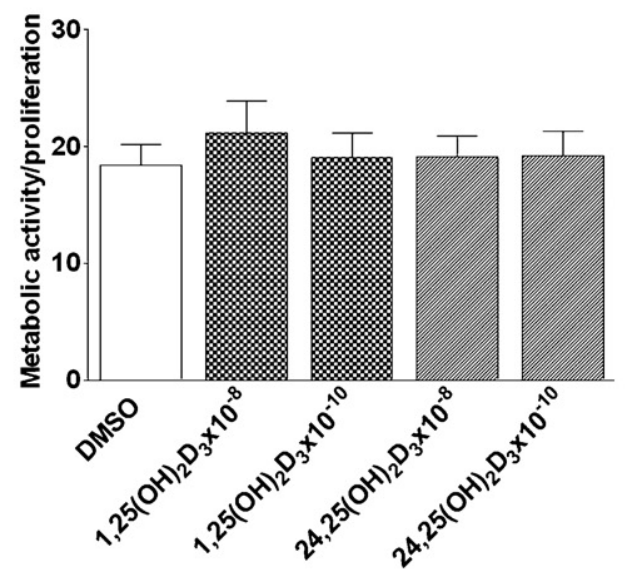

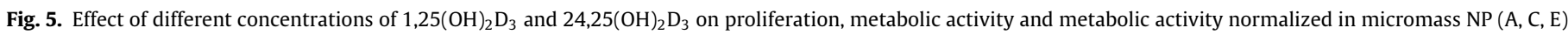
and $\mathrm{AF}(\mathrm{B}, \mathrm{D}, \mathrm{F})$ cells. $n=10$ experiments.

For what concern normalized metabolic activity, we did not observed differences at 2 or 6 days for NP cells (Fig. 3E) while for AF cells after 6 days of treatment with $10^{-8} \mathrm{M} 1,25(\mathrm{OH})_{2} \mathrm{D}_{3}$ it was significant $(p \leq 0.0005)$ increased in comparison with cells differently treated (Fig. 3F).
The evidences of the $10^{-8} \mathrm{M} 1,25(\mathrm{OH})_{2} \mathrm{D}_{3}$-mediated inhibition of proliferation was further confirmed for long term treatment, maintaining cells in culture with the active metabolite for 12 days. Fig. 4 shows the significant reduction $(p \leq 0.05)$ of proliferation (A) for both $\mathrm{NP}(57 \pm 5 \%)$ and $\mathrm{AF}(64 \pm 24 \%)$ and metabolic activity 
(B) $(p \leq 0.005)$ for NP $(72 \pm 6 \%)$ and $(p \leq 0.0005) \mathrm{AF}(68 \pm 13 \%)$ in comparison with DMSO (100\%) treated cells. For what concern normalized metabolic activity, we did not observed differences for AF cells while for NP cells after 12 days of treatment with $10^{-8} \mathrm{M}$ $1,25(\mathrm{OH})_{2} \mathrm{D}_{3}$ it was significantly increased $(p \leq 0.05 ; 128 \pm 24 \%)$ in comparison with DMSO (100\%) treated cells (Fig. 4C).

In micromass cultures we did not registered significant differences for both the tested parameters in NP and AF cells after 28 days in culture and treatment with the different concentrations of the two metabolites (Fig. 5).

\subsection{Effect of $1,25(\mathrm{OH})_{2} D_{3}$ on matrix and VDR genes expression in monolayer}

Starting from the effect observed for $10^{-8} \mathrm{M} 1,25(\mathrm{OH})_{2} \mathrm{D}_{3}$ on proliferation and metabolic activity, we evaluated if the same concentration of the active metabolite was able to modulate the expression of genes encoding for the main IVD ECM components.

We did not observe any significant difference in aggrecan gene expression in NP cells, while AF cells showed a significant $(p \leq 0.05)$ down-regulation of the gene expression $(70 \pm 29 \%)$ in comparison with control DMSO-treated cells (Fig. 6A). The same levels of expression of aggrecan gene were registered in NP and AF control cells.

The stronger down-regulation of genes expression was observed for collagen genes. COL1A1 showed a significant decrease $(p \leq 0.005)$ in NP and AF cells $10^{-8} \mathrm{M} 1,25(\mathrm{OH})_{2} \mathrm{D}_{3}$ treated $(53 \pm 22 \%$ and $58 \pm 22 \%$, respectively) in comparison with control (100\%) (Fig. 6B). For COL2A1 was observed a significant reduction ( $p \leq 0.005$ and $p \leq 0.05$, respectively) for both cell types ( $29 \pm 13$ and $36 \pm 27$, respectively), in cells treated with the metabolite in comparison with control (100\%) (Fig. 6C). Moreover, control culture recorded higher levels of collagen I than collagen II expression and similar levels of collagen I expression in NP and AF cells, but lower levels of collagen II in AF cells respect to NP cells.

Finally, we analyzed the VDR expression following $10^{-8} \mathrm{M}$ $1,25(\mathrm{OH})_{2} \mathrm{D}_{3}$ treatment, but no significant differences were registered in NP and AF cells after the treatment with the metabolite in comparison with control (Fig. 7A).

\subsection{Effect of $1,25(\mathrm{OH})_{2} D_{3}$ on collagens, GAGs production and} genes expression in micromass culture

DMMB assay revealed no differences in GAGs production for both the cell types after $10^{-8}$ or $10^{-10} \mathrm{M} 1,25(\mathrm{OH})_{2} \mathrm{D}_{3}$ and $24,25(\mathrm{OH})_{2} \mathrm{D}_{3}$ or DMSO treatments, with the exception of AF cells treated with $10^{-8} \mathrm{M} 1,25(\mathrm{OH})_{2} \mathrm{D}_{3}$, showing a significant decrease $(p \leq 0.05)$ (Fig. 8).

Fig. 9 shows that ACAN was significantly down-regulated $(p \leq 0.05 ; 62 \pm 35 \%)$ in AF cells treated with $10^{-8} \mathrm{M} 1,25(\mathrm{OH})_{2} \mathrm{D}_{3}$ respect to DMSO (100\%) treated cells (A), COL1A1 was significantly $(p \leq 0.005)$ more expressed in micromass than monolayer AF cultures and its expression was significantly $(p \leq 0.05 ; 37 \pm 28 \%)$ reduced in AF cells treated with $10^{-8} \mathrm{M} 1,25(\mathrm{OH})_{2} \mathrm{D}_{3}$ in comparison with DMSO (100\%) cells (B).

COL2A1 was more expressed in micromass in comparison with monolayer cultures, but its expression seemed not to be significantly affected by the vitamer in micromass (Fig. 9C).

Finally, no significant differences were registered in vitamin $D_{3}$ receptor gene expression for NP and AF cells following $10^{-8} \mathrm{M}$ $1,25(\mathrm{OH})_{2} \mathrm{D}_{3}$ treatment in comparison with control DMSO treated cells (Fig. 7B). In NP cells VDR expression was significantly $(p \leq 0.05)$ lowered in micromass compared to monolayers.

Histologically, micromass were variably composed of spindleshaped to round cells, often contained in lacuneae and embedded in
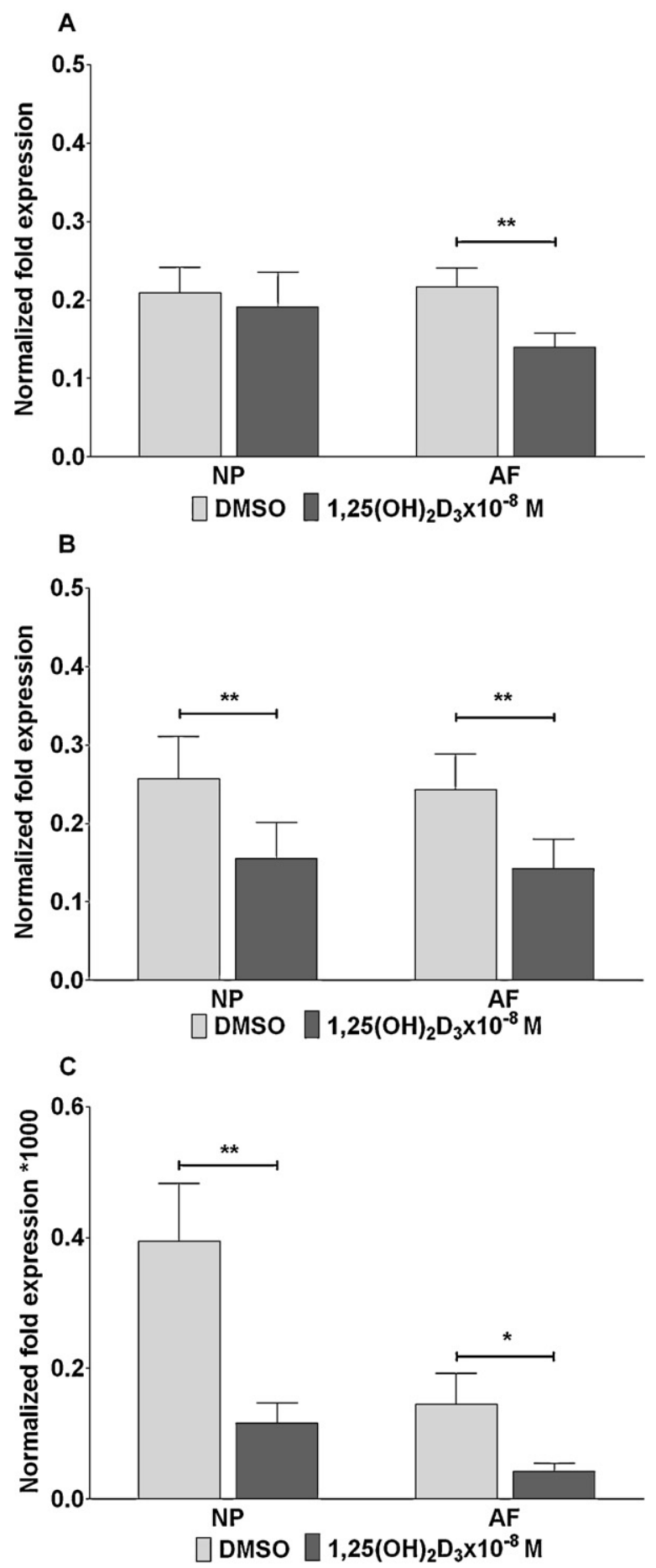

Fig. 6. Effect of $1,25(\mathrm{OH})_{2} \mathrm{D}_{3}$ on aggrecan (A), collagen I (B) and II (C) genes expression in monolayer. Significant differences are marked as follow: ${ }^{*} p \leq 0.05$ and ${ }^{* *} p \leq 0.005 . n=10$ experiments.

moderate to large amount of extracellular matrix, with the overall morphology ranging from mild to almost complete cartilaginous differentiation. According to the Bern Score visual grading system micromass obtained from NP cells had a moderately reduced Alcian blue staining and underwent an overall milder cartilaginous differentiation than the ones from AF cells. In both groups, $10^{-8} \mathrm{M} 1,25(\mathrm{OH}) \mathrm{D}_{3}$ treated micromass underwent a slightly milder differentiation than controls. Based on the immunohistochemical results, collagen II staining was less intense in NP than AF cells, and in $10^{-8} \mathrm{M} 1,25(\mathrm{OH}) \mathrm{D}_{3}$ treated cells than control cells. No 
A

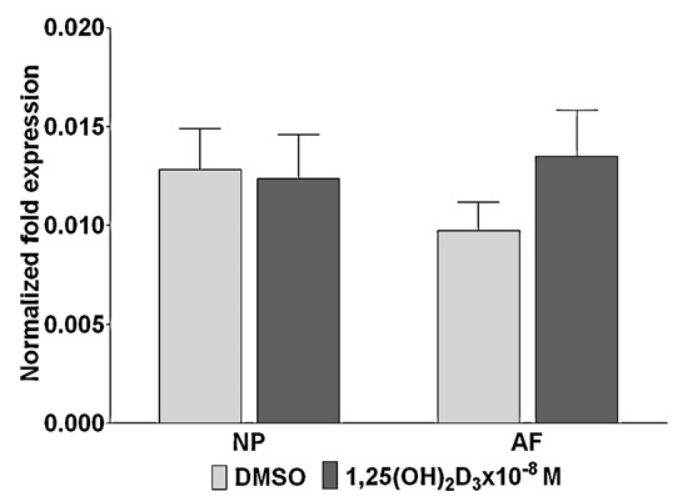

B

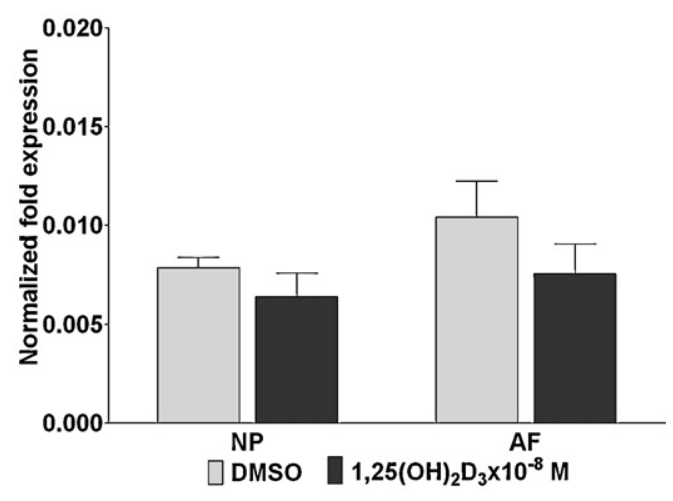

Fig. 7. Effect of $1,25(\mathrm{OH})_{2} \mathrm{D}_{3}$ on VDR gene expression in monolayer (A) and micromass (B) culture. $n=10$ experiments.

relevant differences between NP and AF cells and between $10^{-8} \mathrm{M}$ $1,25(\mathrm{OH}) \mathrm{D}_{3}$-treated and control cells were observed for collagen I staining, except for a mild reduction in AF treated pellets compared to control (Fig. 10).

\section{Discussion}

$1,25(\mathrm{OH})_{2} \mathrm{D}_{3}$ is known to regulate the metabolism of several cell types, including chondrocytes (Klaus et al., 1991; Pedrozo et al., 1999; Schwartz et al., 1997; Krohn et al., 2003; Dean et al., 1996; Sylvia et al., 2002) which respond differently to $1,25(\mathrm{OH})_{2} \mathrm{D}_{3}$ and $24,25(\mathrm{OH})_{2} \mathrm{D}_{3}$, depending on their stage of maturation. Moreover vitamin $\mathrm{D}$ metabolites also have a recognized role in cartilage differentiation and maturation during the process of bone formation at the physis (Boyan et al., 1988).

Firstly, to evaluate the effects of vitamin D active metabolites in IVD cells, we stated by gene expression analysis that not only AF cells, as already demonstrated by in vitro and in vivo immunoistochemical analysis by Gruber et al. (2008), but even NP cells, express VDR.

IVD cells are very sensitive to metabolic stimuli. NP cells respond to FBS concentration: when cultured in $1 \%$ FBS they show a reduced viability and, at morphological level, signs of nutritional factors deprivation, while, in $10 \%$ FBS, they show a higher viability (Zhang et al., 2006). The same effect was observed for AF cells, showing a significant increase of proliferation in culture with $20 \%$ respect to 5\% FBS (Gruber et al., 2008). We also observed that cells proliferation and metabolic activity are influenced by FBS concentrations. However, since we observed good parameters at the lowest FBS tested concentration, to avoid the influence of the vitamin $\mathrm{D}$ binding protein on the active metabolites, we maintained our cells in 5\% FBS when treated.

Following vitamin D active metabolites treatments in monolayer, we recorded an inhibition of the proliferation of both cell types at the highest $1,25(\mathrm{OH})_{2} \mathrm{D}_{3}$ tested concentration after 6 days of treatment and even stronger after 10-12 days in comparison with their DMSO treated counterparts. We did not observe effects mediated by $24,25(\mathrm{OH}) \mathrm{D}_{3}$.

Gruber et al. (2008) also showed that $10^{-8} \mathrm{M} 1,25(\mathrm{OH}) \mathrm{D}_{3}$ addiction in culture medium with 5\% FBS of AF cells maintained for 6 days in monolayer caused a significant decrease of proliferation in comparison with control cells in culture with 20\% FBS. Our data confirmed this evidence for NP and AF cells; moreover, we avoided the possible influence of the different FBS concentrations added in culture on the tested parameters, by reducing the serum percentage to $5 \%$ and using the same FBS concentration for treated and control cells.

$10^{-8} \mathrm{M} 1,25(\mathrm{OH}) \mathrm{D}_{3}$ acts also on the modulation of ECM genes expression in monolayer cultures of both cells types.

The VDR expression did not show significant modification in treated in comparison with control cells, suggesting that the
A

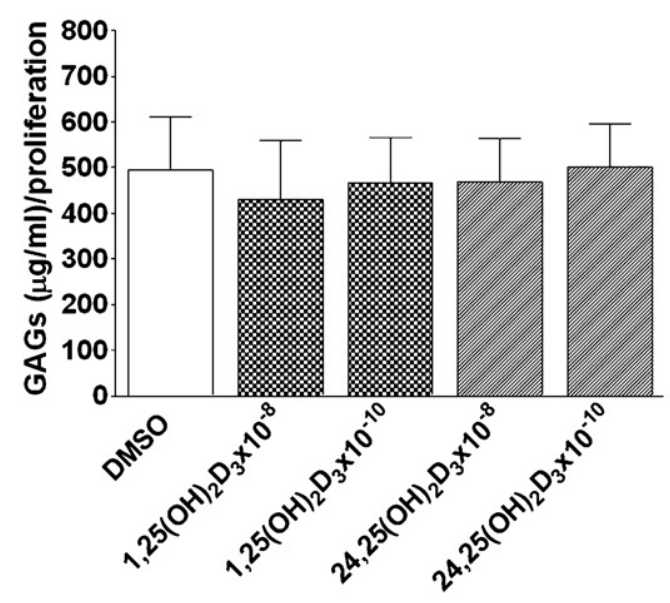

B

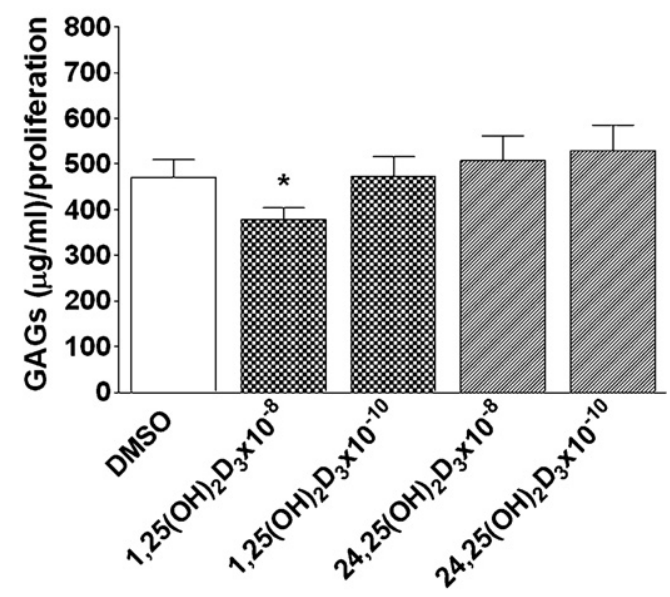

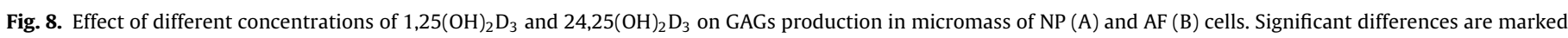
as follow: ${ }^{*} p \leq 0.05$. $n=10$ experiments. 


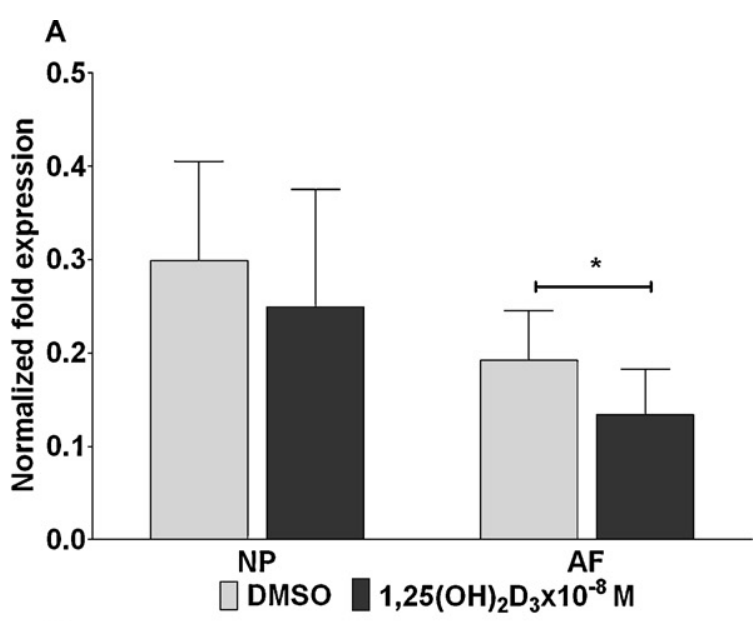

B

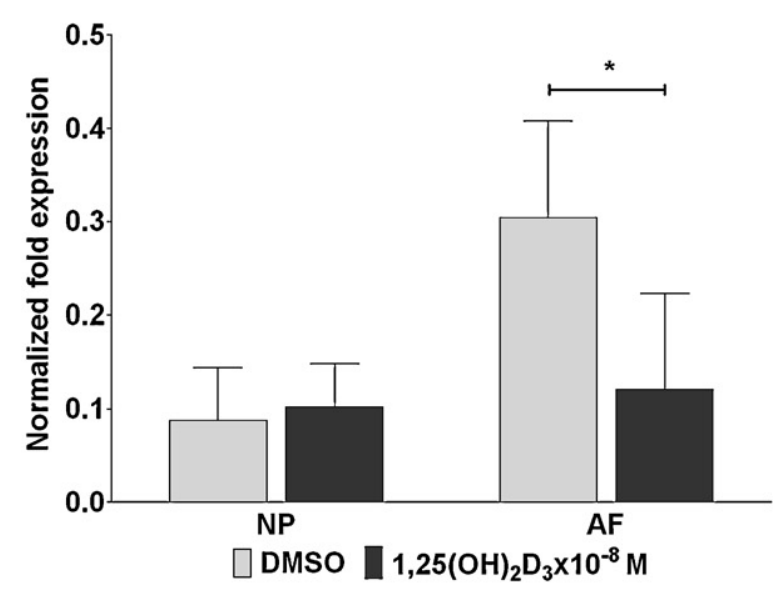

C

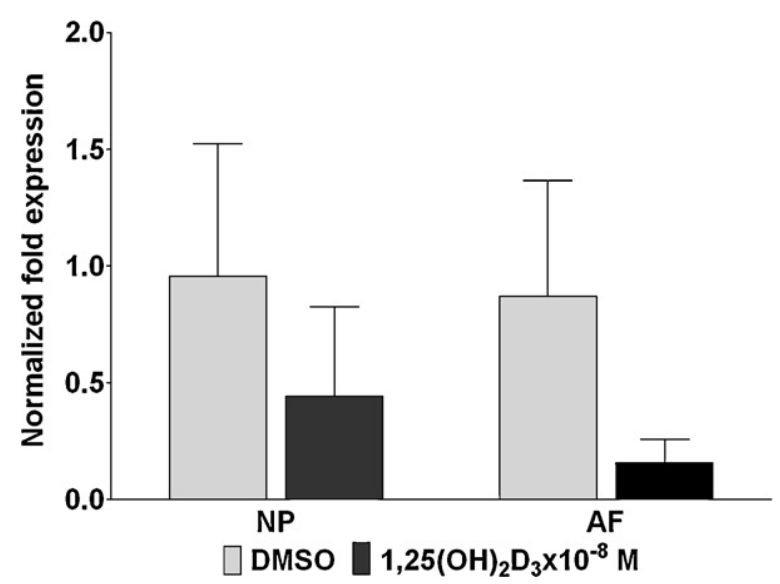

Fig. 9. Effect of $1,25(\mathrm{OH})_{2} \mathrm{D}_{3}$ on aggrecan (A), collagen I (B) and II (C) genes expression in micromass cultures. Significant differences are marked as follow: ${ }^{*} p \leq 0.05$. $n=10$ experiments.

observed metabolite-mediated effects did not depend from the variation of the vitamin $\mathrm{D}$ receptor gene expression.

Moreover, in control cells, we registered higher expression levels of collagen I than collagen II and similar levels of collagen I expression in NP and AF cells, but lower levels of collagen II in AF cells than in NP cells. This could be explained considering that chondrocytes and IVD cells in monolayer culture are characterized by decreased synthesis of type II collagen and increased synthesis of type I collagen (Benya and Shaffer, 1982; Wang et al., 2001).
For this reason we conduced our experiments also in micromass cultures, to mimic a more physiological microenvironment for the cells, allowing the phenotypic expression of type II collagen and other ECM components (Lee et al., 2001).

Actually, we did not observe effects on proliferation and metabolic activity in micromass cultures mediated by both the tested metabolites. Since Zhang et al. (2006) observed deep morphological and proliferative modifications of NP cells cultured in medium with TGF- $\beta$, with dose-dependent induction of the proliferation, this could suggest a possible influence of TGF- $\beta$ on discs cells, masking the inhibitory effects on proliferation metabolitesmediated observed in monolayer culture. An interaction of the growth factor with vitamin D active metabolites is also hypothesized whilst a direct vitamin D metabolites modulation of TGF- $\beta$ in a cell maturation specific manner on rat chondrocytes has been reported (Schwartz et al., 1993).

Micromass cultures seem to induce a more physiologic pattern of expression of collagens and aggrecan in comparison with monolayer cultures for both NP and AF cells.

Some authors proposed the tridimensional culture as a model to study discs cells ECM metabolism because it is closer to the in vivo condition than monolayer culture: Joon et al. cultured human IVD cells in alginate beads or micromasses and found that proteoglycans and collagen II synthesis increased over their monolayer controls at 3 weeks (Joon et al., 2001); Alini et al. (2003) observed a stable increase in cells density and synthesis of proteoglycan in bovine NP cells cultured on scaffolds.

In the present work, treatment of NP and AF cells in micromass culture with metabolites did not result in relevant modifications of GAGs production assessed by the DMBB assay, except for AF cells whose GAGs production was reduced after $10^{-8} \mathrm{M} 1,25(\mathrm{OH}) \mathrm{D}_{3}$ treatment.

Histological analysis showed a reduced Alcian blue staining for GAGs in both NP and AF treated pellets compared to control pellets, differently from the observations of Gruber et al. (2008) which showed abundant proteoglycan-containing extracellular matrix in histological preparations of both control and $1,25(\mathrm{OH})_{2} \mathrm{D}_{3}$-treated cells, without differences in GAGs production. The significant reduced ACAN expression in our AF cells in micromass cultures after $1,25(\mathrm{OH})_{2} \mathrm{D}_{3}$ treatment is in accordance with the results from DMMB assay and histology, suggesting that an inhibition of $A C A N$ expression could lead to a reduction in GAGs production and deposition in micromass.

Immunohistochemical data showed a reduction of collagen I and II staining in $\mathrm{AF} 10^{-8} \mathrm{M} 1,25(\mathrm{OH}) \mathrm{D}_{3}$ treated cells in accordance with the observed dowregulation of COL1A1 and COL2A1 expression, although the latter was not statistically significative, probably caused by the great variability of expression in the different samples or by the influence of the TGF- $\beta$, simulating collagen II synthesis and thus counteracting the effect of the metabolite.

Finally, as for monolayer cultures, VDR expression in micromass was not influenced by $1,25(\mathrm{OH})_{2} \mathrm{D}_{3}$ treatment and thus the metabolite seems to act without up or down-regulating the expression of its receptor. Only in NP cells VDR is significantly less expressed in micromass than in monolayer: since the down-regulating effects on collagens genes were observed in monolayer for both the cell types and in micromass only for AF cells, probably the reduced $V D R$ expression in NP cells in tridimentional culture, and the possible TGF- $\beta$-metabolite interaction, account for the lack of effects vitamin D mediated in NP micromass culture.

The observed results could help to understand the biochemical mechanisms modulated in disc cartilage by vitamin D. Further studies should be conducted to deeper the observed effects of the vitamer on the inhibition of the proliferation (e.g. cell cycle analysis) and on the down-regulation of ECM genes expression (e.g. studies of genes methylation pattern or evaluation of the possible 
A
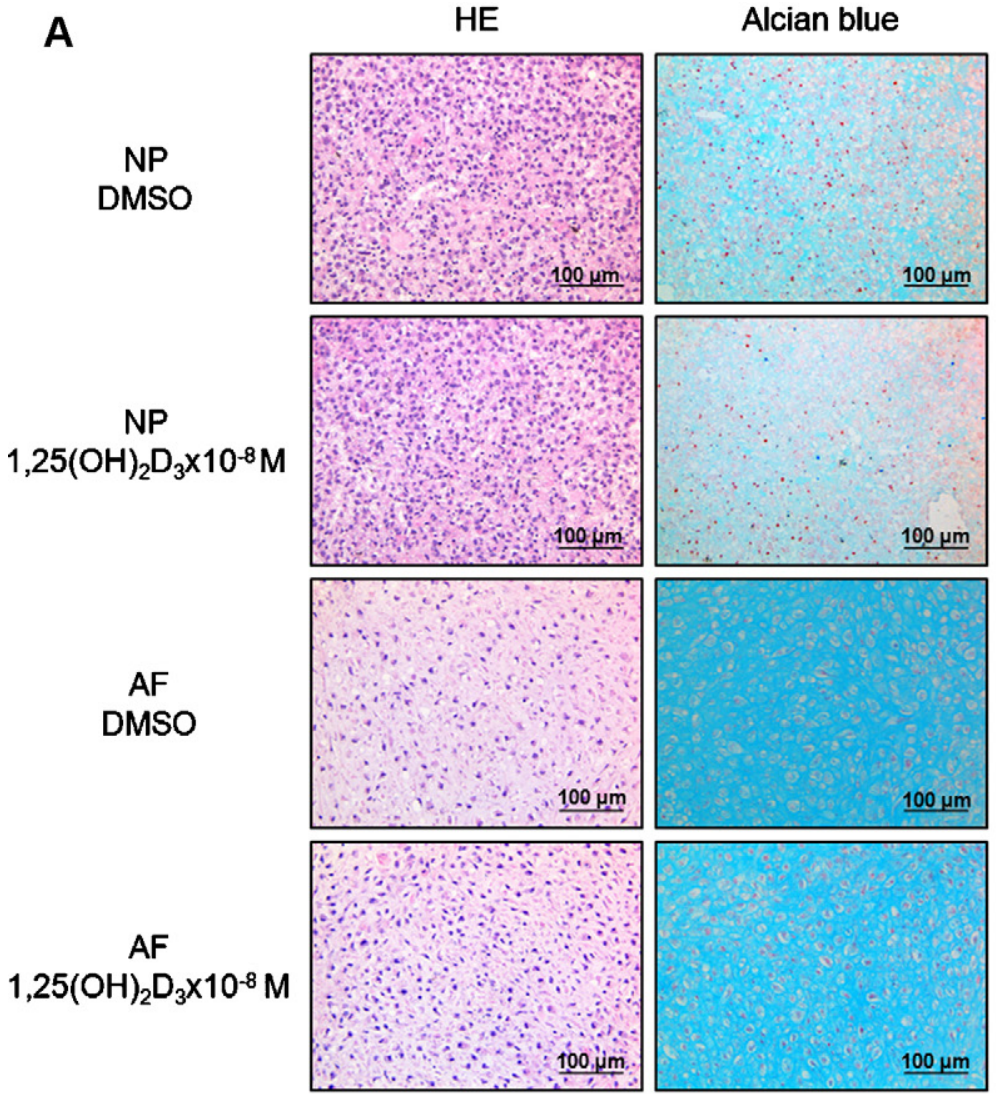

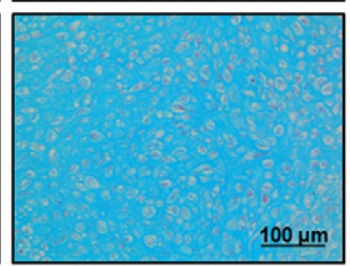

Alcian blue
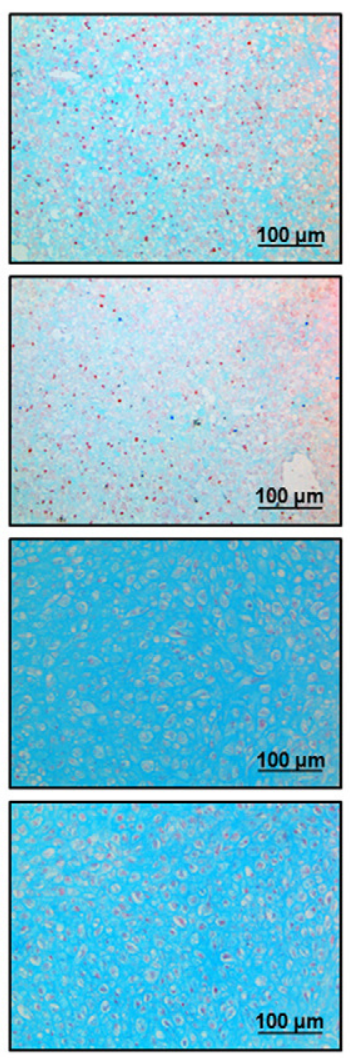

Collagen I
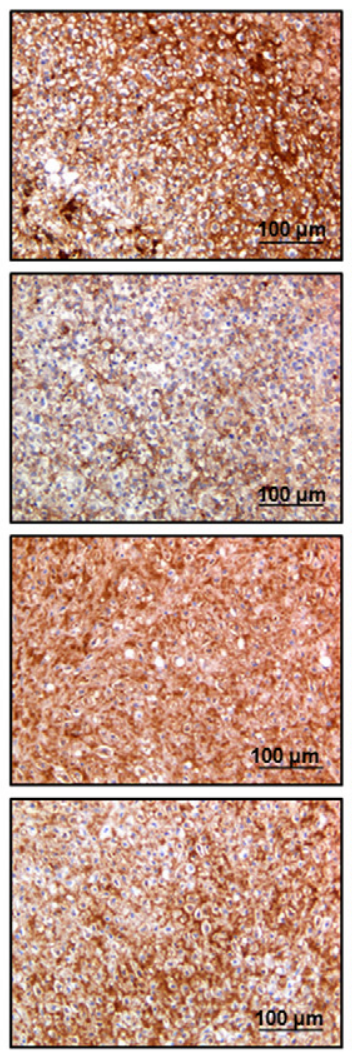

Collagen II
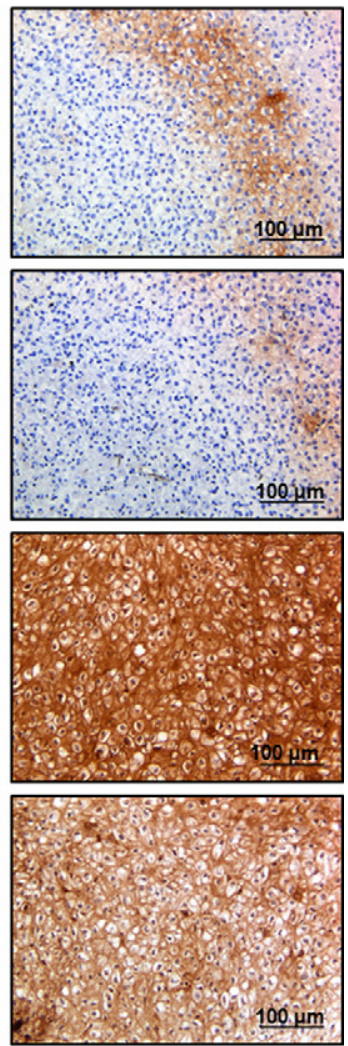

B

\begin{tabular}{|c|c|c|c|c|c|c|c|}
\cline { 2 - 7 } \multicolumn{2}{c|}{} & $\begin{array}{c}\text { Alcian } \\
\text { blue }\end{array}$ & Cell distance & $\begin{array}{c}\text { Cell } \\
\text { morphology }\end{array}$ & $\begin{array}{c}\text { Total } \\
\text { score }\end{array}$ & $\begin{array}{c}\text { Collagen } \\
\text { I }\end{array}$ & $\begin{array}{c}\text { Collagen } \\
\text { II }\end{array}$ \\
\hline \multirow{2}{*}{$\mathrm{NP}$} & $\mathrm{DMSO}$ & 1,50 & 2,25 & 2,50 & 6,25 & 1,75 & 0,88 \\
\cline { 2 - 8 } & $1,25(\mathrm{OH})_{2} \mathrm{D}_{3} \times 10^{-8} \mathrm{M}$ & 1,25 & 2,14 & 2,57 & 6,00 & 1,63 & 0,63 \\
\hline \multirow{2}{*}{$\mathrm{AF}$} & $\mathrm{DMSO}$ & 2,45 & 2,18 & 2,45 & 7,09 & 1,91 & 2,09 \\
\cline { 2 - 8 } & $1,25(\mathrm{OH})_{2} \mathrm{D}_{3} \times 10^{-8} \mathrm{M}$ & 2,22 & 2,22 & 2,33 & 6,78 & 1,56 & 1,44 \\
\hline
\end{tabular}

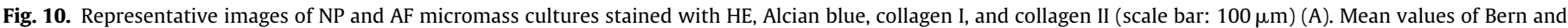
immunohistochemical scores applied for the evaluation of NP and AF micromass cultures (B).

pathways vitamin D regulated in IVD cells). Moreover, the interaction between TGF- $\beta$ and the vitamer should be considered for a better evaluation of the obtained results from micromass cultures.

\section{Conclusion}

NP and AF cells express VDR and are very sensitive to factors contained in FBS able to influence their proliferation and metabolic activity.

$10^{-8} \mathrm{M} 1,25(\mathrm{OH}) \mathrm{D}_{3}$ inhibited proliferation of both cell types in monolayer but not in micromass culture and modulated ECM matrix genes expression and proteins production of NP and AF cells in monolayer and micromass.

The observed metabolite-mediated effects seemed not dependent from the variation of the VDR expression.

\section{Acknowledgements}

The authors would like to thank Maria Grazia Fontaneto, Cristina Ciavarro and Marco Zambotti for patients recruitment and data entry.
This work was supported by European Community's Seventh Framework Programme (FP7, 2007-2013 under Grant Agreement No. HEALTH-F2-2008-201626).

\section{References}

Alini M, Wei L, Markovic P, Aebi M, Spiro RC, Roughley PJ. The potential and limitations of a cell-seeded collagen/hyaluronan scaffold to engineer an intervertebral disc-like matrix. Spine 2003;28:446-54.

Atkin I, Pita JC, Ornoy A, Agundez A, Castiglione G, Howell DS. Effects of vitamin D metabolites on healing of low phosphate, vitamin D-deficient induced rickets in rats. Bone 1985;6:113-23.

Balabanova S, Richter H-P, Antoniadis G, Homoki J, Kremmer N, Hanle J, et al. 25hydroxyvitamin D, 24,25-dihydroxyvitaminD and 1,25-dihydroxyvitaminD in human cerebrospinal fluid. Klin Wochenschr 1984;62:1086-90.

Balmain N, Hauchecorne M, Pike JW, Cuisinier-Gleizes P, Mathieu H. Distribution and subcellular immunolocalization of 1,25-dihydroxyvitamin D3 receptors in rat epiphyseal cartilage. Cell Mol Biol (Noisy-le-grand) 1993;39:339-50.

Benya PD, Shaffer JD. Dedifferentiated chondrocytes reexpress the differentiated collagen phenotype when cultured in agarose gels. Cell 1982;30:215-24.

Boyan BD, Schwartz Z, Swain LD, Carnes Jr DL, Zislis T. Differential expression of pheno-type by resting zone and growth region costochondral chondrocytes in vitro. Bone 1988;9:185-94.

Colombini A, Lombardi G, Corsi MMC, Banfi G. Pathophysiology of the human intervertebral disc. Int J Biochem Cell Biol 2008;40:837-42.

Corvol MT, Dumontier MF, Maroteaux P, Rappaport R, Guyda M, Posner B. Culture of normal and pathological human growth cartilage. Action of vitamin D derivatives and somatomedin. Arch Fr Pediatr 1978;35:57-64. 
Corvol MT, Dumontier MF, Tsagris L, Lang F, Bourguignon J. Cartilage and vitamin D in vitro. Ann Endocrinol (Paris) 1981;42:482-7.

Dean DD, Boyan BD, Muniz OE, Howell DS, Schwartz Z. Vitamin D metabolites regulate matrix vesicle metalloproteinase content in a cell maturation-dependent manner. Calcif Tissue Int 1996;59:109-16.

Dickson IR, Maher PM. The influence of vitamin D metabolites on collagen synthesis by chick cartilage in organ culture. J Endocrinol 1985;105: 79-85.

Farndale RW, Buttle DJ, Barrett AJ. Improved quantitation and discrimination of sulphated glycosaminoglycans by use of dimethylmethylene blue. Biochim Biophys Acta 1986;883:173-7.

Garabedian M, Du Bois MB, Corvol MT, Pezant E, Balsan S. Vitamin D and cartilage. I. In vitro metabolism of 25-hydroxycholecalciferol by cartilage. Endocrinology 1978;102:1262-8.

Grogan SP, Barbero A, Winkelmann V, Rieser F, Fitzsimmons JS, O’Driscoll S, Martin I, Mainil-Varlet P. Visual histological grading system for the evaluation of in vitro-generated neocartilage. Tissue Eng 2006;12:2141-9.

Gruber HE, Hoelscher G, Ingram JA, Chow Y, Loeffler B, Hanley EN. 1,25(OH)2-vitamin D3 inhibits proliferation and decreases production of monocyte chemoattractant protein-1, thrombopoietin, VEGF, and angiogenin by human annulus cells in vitro. Spine 2008;33:755-65.

Harmand MF, Thomasset M, Rouais F, Ducassou D. In vitro stimulation of articular chondrocyte differentiated function by 1,25 -dihydroxycholecalciferol or 24R,25-dihydroxycholecalciferol. J Cell Physiol 1984;119:359-65.

Holick MF. Vitamin D: importance in the prevention of cancers, type 1 diabetes, heart disease, and osteoporosis. Am J Clin Nutr 2004;79:362-71.

Jones G, White C, Sambrook P, Eisman J. Allelic variation in the vitamin D receptor, lifestyle factors and lumbar spinal degenerative disease. Ann Rheum Dis 1998;57:94-9.

Joon YL, Ronald H, Dalip P, Cassinelli E, Usas A, Gilbertson L, et al. New use of a three-dimensional micromass culture system for human intervertebral disc cells. Spine $2001 ; 26: 2316-22$.

Kawaguchi Y, Kanamori M, Ishihara H, Ohmori K, Matsui H, Kimura T. The association of lumbar disc disease with vitamin-D receptor gene polymorphism. J Bone Joint Surg Am A 2002;84:2022-8.

Klaus G, Merke J, Eing H, Hügel U, Milde P, Reichel H, et al. 1,25(OH)2D3 receptor regulation and $1,25(\mathrm{OH}) 2 \mathrm{D} 3$ effects in primary cultures of growth cartilage cells of the rat. Calcif Tissue Int 1991;49:340-8.

Krohn K, Haffner D, Hügel U, Himmele R, Klaus G, Mehls O, et al. 1,25(OH)2D3 and dihydrotestosterone interact to regulate proliferation and differentiation of epiphyseal chondrocytes. Calcif Tissue Int 2003;73:400-10.

Lee JY, Hall R, Pelinkovic D, Cassinelli E, Usas A, Gilbertson L, et al. New use of a three-dimensional micromass culture system for human intervertebral disc cells: initial characterization and potential use for tissue engineering. Spine 2001;26:2316-22.
Mackay AM, Beck SC, Murphy FP, Chichester CO, Pittenger MF. Chondrogenic differentiation of cultured Human mesenchymal stem cells marrow. Tissue Eng 1998;4:415-28.

Neidlinger-Wilke C, Wurtz K, Liedert A, Schmidt C, Börm W, Ignatius A, et al. A threedimensional collagen matrix as a suitable culture system for the comparison of cyclic strain and hydrostatic pressure effects on intervertebral disc cells. Neurosurg Spine 2005;2:457-65.

Nemere I, Schwartz Z, Pedrozo H, Sylvia VL, Dean DD, Boyan BD. Identification of a membrane receptor for 1,25 -dihydroxyvitamin $D_{3}$ which mediates rapid activation of protein kinase C. J Bone Miner Res 1998;13:1353-9.

Pedrozo HA, Schwartz Z, Mokeyev T, Ornoy A, Xin-Sheng W, Bonewald LF, et al. Vitamin D3 metabolites regulate LTBP1 and latent TGF-b1 incorporation in the extracellular matrix of chondrocytes. J Cell Biochem 1999;72:151-65.

Pfirrmann CW, Metzdorf A, Zanetti M, Hodler J, Boos N. Magnetic resonance classification of lumbar intervertebral disc degeneration. Spine 2001;26:1873-8.

Roberts S, Evan H, Trivedi J, Menage J. Histology and pathology of the human intervertebral disc. J Bone Joint Surg Am 2006;88:10-4.

Schmitz JP, Schwartz Z, Sylvia VL, Dean DD, Calderon F, Boyan BD. Vitamin D3 regulation of stromelysin-1 (MMP-3) in chondrocyte cultures is mediated by protein kinase C. J Cell Physiol 1996;168:570-9.

Schwartz Z, Bonewald LF, Caulfield K, Brooks B, Boyan BD. Direct effects of transforming growth factor-b on chondrocytes are modulated by vitamin $\mathrm{D}$ metabolites in a cell maturation-specific manner. Endocrinology 1993;132:1544-52.

Schwartz Z, Finer Y, Nasatzky E, Soskolne WA, Dean DD, Boyan BD, et al. The effects of $17 \mathrm{~b}$-estradiol on chondrocyte differentiation are modulated by vitamin D3 metabolites. Endocrine 1997;7:209-18.

Setton LA, Chen J. Cell mechanics and mechanobiology in the intervertebral disc Spine (Phila Pa 1976) 2004;29:2710-23.

Sylvia VL, Gay I, Hardin R, Dean DD, Boyan BD, Schwartz Z. Rat costochondral chondrocytes produce $17 \mathrm{~b}$-estradiol and regulate its production by $1 \mathrm{a}, 25(\mathrm{OH}) 2 \mathrm{D} 3$. Bone 2002;30:57-63.

Urban JPG, Roberts S. Degeneration of the intervertebral disc. Arthritis Res Ther 2003;5:120-30.

Videman T, Gibbons LE, Battie MC, Maravilla K, Vanninen E, Leppävuori J, et al. The relative roles of intragenic polymorphisms of the vitamin $D$ receptor gene in lumbar spine degeneration and bone density. Spine 2001;26:E7-12.

Videman T, Leppävuori J, Kaprio J, Battié MC, Gibbons LE, Peltonen L, et al. Volvo Award winner in basic science studies - intragenic polymorphisms of the vitamin $\mathrm{D}$ receptor gene associated with intervertebral disc degeneration. Spine 1998;23:2477-85.

Wang JY, Baer AE, Kraus VB, Setton LA. Intervertebral disc cells exhibit differences in gene expression in alginate and monolayer culture. Spine $2001 ; 26: 1747-51$

Zhang R, Ruan D, Zhang C. Effects of TGF-beta1 and IGF-1 on proliferation of human nucleus pulposus cells in medium with different serum concentrations. J Orthop Surg Res 2006;1:9. 